\title{
Prevalence of strongyloidiasis in Peru: systematic review and meta-analysis
}

\author{
Sonia Ortiz-Martínez ${ }^{1 \dagger}$, José-Manuel Ramos-Rincón ${ }^{2,3^{*}+}$ (D), María-Esteyner Vásquez-Chasnamote ${ }^{4}$, \\ Olga-Nohelia Gamboa-Paredes ${ }^{5}$, Katty-Madeleine Arista-Flores ${ }^{5}$, Luis-Alfredo Espinoza-Venegas ${ }^{6}$, \\ Eva de-Miguel-Balsa ${ }^{2,7}$, Viviana-Vanessa Pinedo-Cancino ${ }^{8}$, Miguel Górgolas-Hernández-Mora9 ${ }^{9,10 \dagger}$ and \\ Martín Casapía-Morales ${ }^{6,11,12+}$
}

\begin{abstract}
Background: Strongyloidiasis is a disease of great public health significance, caused by the parasitic nematodes Strongyloides stercoralis, Strongyloides fuelleborni, and Strongyloides fuelleborni subsp. kellyi. This systematic review and meta-analysis aimed to assess the prevalence of Strongyloides stercoralis infection in Peru.

Methods: The review was based on a literature search in PubMed, SciELO and Google Scholar using the key words or root words "strongyl*" AND "Peru" on 15 July 2020. Eligible studies were published from 1 January 1981 to 15 July 2020 and written in English, Spanish, Italian, or French.
\end{abstract}

Results: We included 21 papers in the analysis. Studies were heterogeneous in terms of study population and diagnostic methods (e.g. Baermann technique, agar, Dancescu or charcoal cultures, serology, string capsule). Prevalence of S. stercoralis ranged from 0.3 to 45\%. The pooled proportion of Strongyloides in the general population was $7.34 \%$ (95\% Cl 4.97 to 10.13\%). Half the studies were designed to detect parasites in general. In studies designed to detect $\mathrm{S}$. stercoralis, the most widely used diagnostic method was the Baermann technique.

Conclusion: Prevalence of S. stercoralis in Peru was high but varied by geographic area, techniques for stool examination, and participant characteristics.

Keywords: Strongyloides stercoralis, Serology, Seroprevalence, Prevalence, Peru

\section{Background}

Strongyloidiasis is a chronic, neglected disease, caused by the nematodes Strongyloides stercoralis, Strongyloides fuelleborni, and Strongyloides fuelleborni subsp. kellyi [1]. This soil-transmitted helminthiasis is believed to affect around 370 million people worldwide [2, 3], but

\footnotetext{
* Correspondence: jramosrincon@yahoo.es

†'Sonia Ortiz-Martínez, José-Manuel Ramos-Rincón, Miguel Górgolas-

Hernández-Mora and Martin Casapía-Morales contributed equally to this work.

${ }^{2}$ Clinical Medicine Department, University Miguel Hernández of Elche, Ctra N-332, 03550 Sant Joan d'Alacant, Alicante, Spain

${ }^{3}$ Internal Medicine Service, General University Hospital of Alicante-ISABIAL, Alicante, Spain

Full list of author information is available at the end of the article
}

prevalence could actually be much higher; a 2017 study estimated global prevalence at $8.1 \%$, or 613.9 million people [4]. Strongyloides stercoralis is endemic to tropical and subtropical regions, but it can be found anywhere with an increased risk of fecal contamination due to poor sanitation, inadequate water supply, or other factors $[1,2]$. Infection rates and risk vary among different population groups [5]. S. stercoralis is the most widely spread species and the only one capable of autoinfection. Untreated, the infection can persist for years to decades and cause considerable morbidity and mortality [6]. Ivermectin, a broad spectrum antiparasitic drug that is used frequently in humans, is the most effective drug against S. stercoralis.

(c) The Author(s). 2021 Open Access This article is licensed under a Creative Commons Attribution 4.0 International License, which permits use, sharing, adaptation, distribution and reproduction in any medium or format, as long as you give appropriate credit to the original author(s) and the source, provide a link to the Creative Commons licence, and indicate if changes were made. The images or other third party material in this article are included in the article's Creative Commons licence, unless indicated otherwise in a credit line to the material. If material is not included in the article's Creative Commons licence and your intended use is not permitted by statutory regulation or exceeds the permitted use, you will need to obtain permission directly from the copyright holder. To view a copy of this licence, visit http://creativecommons.org/licenses/by/4.0/. The Creative Commons Public Domain Dedication waiver (http://creativecommons.org/publicdomain/zero/1.0/) applies to the data made available in this article, unless otherwise stated in a credit line to the data. 
More broadly, intestinal parasitosis is a public health problem in Peru, with an estimated one out of every three Peruvians carrying at least one parasite in their intestines. Studies have shown that strongyloidiasis is highly prevalent in Peruvian rainforest communities but less so in the mountains and coastal areas [7, 8]. Currently there are no national policies that promote the eradication of $S$. stercoralis in children or adults in Peru [9].

The Ministry of Health in Peru reviewed the crosssectional prevalence studies of $S$. stercoralis infection from different areas of the country between 1981 and 2001 [10]. Mean prevalence was $6.6 \%$, with variations by location and diagnostic methods. Despite the high prevalence of the infection, there is limited knowledge of its epidemiology and sero-epidemiology [11].

The difficulty in diagnosing S. stercoralis lies in the absence of a reliable gold standard diagnostic test. Although in some studies the Baermann technique has been shown to be superior to agar plate culture (APC), in others APC is more sensitive than Dancescu or charcoal cultures, the Baermann technique and spontaneous sedimentation in tube technique (SSTT). In contrast, the method with the lowest sensitivity is direct examination. Serology overestimates the burden of disease in endemic countries due to the cross-reactivity with other nematode infections [7, 12].

The sensitivity of diagnostic methods improves with a larger number of stool samples collected; three stool samples can increase the detection sensitivity by up to $7 \%$, while seven stool samples yield a sensitivity of almost $100 \%$ [1, 13].

This systematic literature review and meta-analysis aimed to assess the prevalence of $S$. stercoralis infection in Peru.

\section{Methods}

We performed an electronic search in PubMed and SciELO on 15 July 2020, using the following key words or root words, grouped into two main concepts: "strongyl*" AND "Peru". Results were restricted to studies published from 1 January 1981 to 15 July 2020; performed in humans; and written in English, Spanish, Italian, or French. We sought to identify additional records through backward reference searching and electronic searches for grey literature (Google and Google Scholar).

We assessed surveys, notes, analyses, and epidemiological reports on the prevalence of intestinal protozoa and helminths in general or strongyloidiasis in particular. Two authors screened the titles and abstracts for relevance, retrieving the full texts of all eligible or potentially eligible articles. Data on the prevalence of $S$. stercoralis were collected regardless of the population characteristics (children, adults, immunocompromised patients, etc.). Study characteristics were also collected, including population, study design, diagnostic procedure, and type of fecal examination technique (e.g. modified Baermann technique).

We performed a proportion meta-analysis of prevalence estimates, using the Stuart-Ord (inverse double arcsine square root) method (random-effects model) to calculate the $95 \%$ coefficient intervals and create the forest plots. Heterogeneity was analyzed using the $\mathrm{I}^{2}$ statistic [14]. Publication bias was investigated with funnel plot and confirmed with Egger's test. Meta-analyses were performed with StatsDirect Statstical Software v. 3.3.4 (StatsDirect Ltd., Merseyside, UK).

The prevalence meta-analysis was presented according to three population groups: general population, children, and adults.

\section{Results}

The electronic search in PubMed and SciELO yielded 147 records, and 21 papers were identified through additional searches. After screening the titles and abstracts, we examined the full text of 42 potentially relevant papers, excluding 21 that reported the prevalence of other helminthic infections or did not report prevalence data. The remaining 21 studies were included. Figure 1 shows the flow chart for study selection.

All studies used a cross-sectional, descriptive, observational design, except one systematic review, performed by the Peruvian Ministry of Health, which collected 294 parasite prevalence studies between 1981 and 2001 [10].

The study populations were very heterogeneous: three papers included the adult population (over 15 years old) [15-17], eight were in children [8, 9, 18-23], and nine studied both adults and children [7, 10, 11, 24-29]. One study included only people infected with HIV [15] and another only pregnant women [17].

Most studies described symptomatology. In one study, participants with strongyloidiasis were asymptomatic [20], while in another, authors mentioned only anemia [27]. Six studies did not discuss symptoms [7, 11, 22, 25, 28, 30].

Half the studies were designed to detect parasites in general. Among those designed specifically to study $S$. stercoralis, 10 used the Baermann technique for diagnosis [7, 9-11, 15-17, 21, 25, 29]. Seven studies used agar, Dancescu or charcoal cultures [7, 9-11, 17, 21, 29]; two performed specific serological tests [11, 17]; and one employed a string capsule/enterotest [30]. Other diagnostic techniques used to detect the presence of larvae in stool samples included direct smear of feces in saline-Lugol iodine stain, spontaneous tube sedimentation, formalin-ethyl acetate concentration, and HaradaMori filter paper culture.

The studies in which culture and Baermann's technique were used as diagnostic methods reported higher 


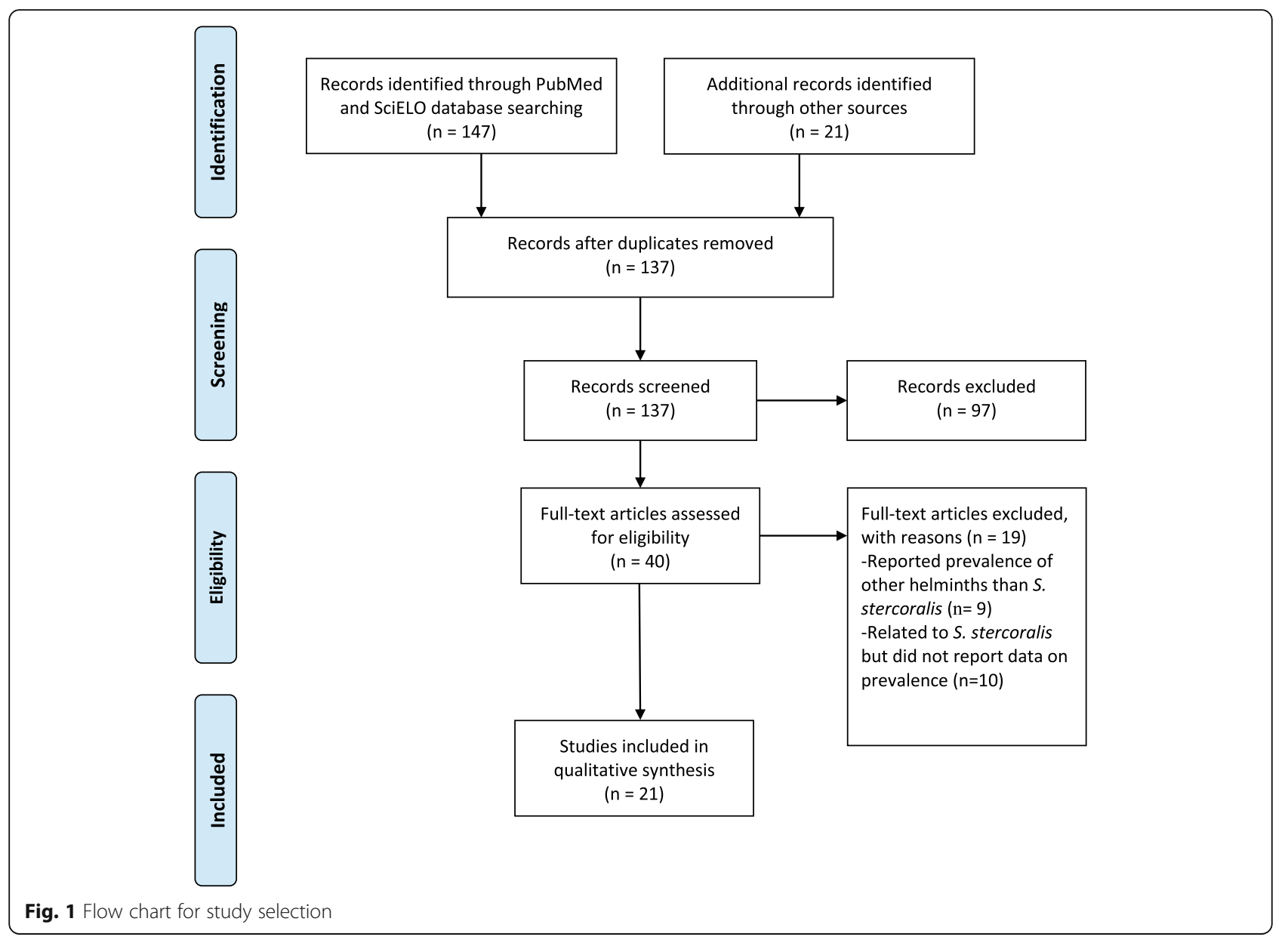

prevalence than those that only used the direct examination or Kato-Katz [22, 26].

Regarding sample collection, most studies collected a single stool sample; four studies used more than one $[15,19,23,24]$. Investigators in four studies also collected blood samples, in two cases for performing $S$. stercoralis serology [11, 17], in two for assessing anemia $[17,27]$, and in one for evaluating eosinophilia [22].

Table 1 presents a summary of the characteristics of included studies [7-27]. Estimated prevalence of strongyloidiasis ranged from 0.3 to $45 \%$ [7, 26], depending on the geographic study area, the techniques used for stool examination, and participant characteristics (e.g. those with diarrhea versus asymptomatic individuals); overall rates were stable over the study period.

The highest prevalence (45\%) was reported in 20 patients attended in the Military Hospital in Iquitos [16]. The study with the second highest prevalence (38.5\%) took place in the Native Community of Nagazú in the Pasco region of the Peruvian Amazon, a central rainforest region recognized as endemic to $S$. stercoralis [7]. Other studies showed high prevalence in the Cusco region $(24.5 \%)$ and in participants with diarrhea in Puerto
Maldonado (19.5\%) [24, 29]. Morales et al. reported a higher prevalence of Strongyloides infection at low altitudes (26.4\%) compared to mountainous regions (18.6\%) [29]. Low prevalence, of 0.3 to $1.5 \%$ of the sample population, was also observed in Chacas and in children living in Jauja (Junin department) $[8,19,20,22,25,26]$.

Most studies discussed coinfection with various helminths. In a study in Puerto Maldonado (Peruvian Amazon), nearly half the participants (47.1\%) infected with $S$. stercoralis were coinfected with Ancylostoma duodenale [24]. In Tarapoto [18], 42\% of total participants had parasitic coinfections; the most common pair was Ascaris lumbricoides and Trichuris trichura. In four provinces of the department of Lima [28], biparasitosis was 32.7\%; authors did not report the most common association. The study reporting the fewest mixed parasitic infections (8.3\%) involved $217 \mathrm{HIV}$ patients at the Cayetano Heredia National Hospital in Lima [15].

The pooled proportion of Strongyloides in the general population was $7.34 \%$ (95\% CI 4.97 to $10.13 \%$; $\mathrm{I}^{2}$ 97.51\%). Table 2 summarizes the results of pooled prevalence in pediatric and adult populations, assuming a random-effects model. As expected, we found high 
Table 1 Peruvian studies of Strongyloides stercoralis infection

\begin{tabular}{|c|c|c|c|c|}
\hline Study ID & Setting (department) [altitude] & Population & Diagnostic procedure & $\begin{array}{l}\text { Prevalence } \\
\text { estimate }\end{array}$ \\
\hline $\begin{array}{l}\text { Huaroto } \\
\text { Sedda } 1990 \\
\text { [30] }\end{array}$ & $\begin{array}{l}\text { National Hospital "Edgardo Rebagliati Martins" } \\
\text { (Lima) }[160 \mathrm{~m}]\end{array}$ & $\begin{array}{l}1511 \text { patients in } \\
\text { Gastroenterology Service }\end{array}$ & $\begin{array}{l}\text { - String capsule } \\
\text { - Enterotest ( } 1 \text { sample) }\end{array}$ & $2.4 \%$ \\
\hline $\begin{array}{l}\text { Rodriguez } \\
1991[18]\end{array}$ & Tarapoto, Amazon basin (San Martin) [141 m] & 110 preschool children & $\begin{array}{l}\text { - Direct smear } \\
\text { - Faust floaty concentration } \\
\text { - Willis floating } \\
\text { - Graham's tape }\end{array}$ & $16 \%$ \\
\hline $\begin{array}{l}\text { Egido } 2001 \\
{[24]}\end{array}$ & $\begin{array}{l}\text { Clinical Hospital, Puerto Maldonado, Amazon } \\
\text { Basin (Madre de Dios) [139 m] }\end{array}$ & $\begin{array}{l}1133 \text { outpatients with diarrhea } \\
\text { (children and adults) }\end{array}$ & $\begin{array}{l}\text { - Direct fecal smears with saline } \\
\text { solution and Lugol stain ( } 3 \\
\text { samples) }\end{array}$ & $19.5 \%$ \\
\hline $\begin{array}{l}\text { Marcos } \\
\text { Raymundo } \\
2002[19]\end{array}$ & Rural survey, province of Jauja (Junin) [3391 m] & $\begin{array}{l}188 \text { children } \\
\text { ( } 1-16 \text { years old })\end{array}$ & $\begin{array}{l}\text { - Spontaneous tube } \\
\text { sedimentation technique } \\
\text { - Formalin-ether concentration } \\
\text { - Rapid sedimentation } \\
\text { technique, modified by } \\
\text { Lumbreras }\end{array}$ & $1.5 \%$ \\
\hline $\begin{array}{l}\text { Marcos } 2002 \\
{[16]}\end{array}$ & $\begin{array}{l}\text { Hospital cross-sectional study, lquitos (Loreto) } \\
{[100 \mathrm{~m}]}\end{array}$ & $\begin{array}{l}41 \text { adults (20 from Military } \\
\text { Hospital, } 21 \text { from Regional } \\
\text { Hospital) }\end{array}$ & $\begin{array}{l}\text { - Direct microscopy } \\
\text { - Kato-Katz technique } \\
\text { - Spontaneous tube } \\
\text { sedimentation technique } \\
\text { - Modified Baermann method }\end{array}$ & 45 and $4.8 \%$ \\
\hline $\begin{array}{l}\text { Marcos } 2003 \\
{[25]}\end{array}$ & $\begin{array}{l}\text { Community survey, rural and urban populations } \\
\text { of Sandia (Puno) [2135 m] }\end{array}$ & 72 children and adults & $\begin{array}{l}\text { - Direct microscopy } \\
\text { - Kato-Katz technique } \\
\text { - Spontaneous tube } \\
\text { sedimentation technique } \\
\text { - Modified Baermann method }\end{array}$ & $1.4 \%$ \\
\hline $\begin{array}{l}\text { Ministry of } \\
\text { Health } 2003 \\
{[10]}\end{array}$ & Cross-sectional studies (countrywide) & 294 studies and 214,199 people & - Various & $6.6 \%$ \\
\hline $\begin{array}{l}\text { Ibañez } 2004 \\
{[20]}\end{array}$ & $\begin{array}{l}\text { Survey in rural community, Chancay district, } \\
\text { Huaral province (Lima) [43 m] }\end{array}$ & 1049 children (6-15 years old) & $\begin{array}{l}\text { - Direct examination } \\
\text { - Spontaneous tube } \\
\text { sedimentation } \\
\text { - Rapid sedimentation technique } \\
\text { modified by Lumbreras } \\
\text { - Kato-Katz technique } \\
\text { - Baermann method modified } \\
\text { by Lumbreras }\end{array}$ & $0.8 \%$ \\
\hline $\begin{array}{l}\text { Lau Chong } \\
2005[7]\end{array}$ & $\begin{array}{l}\text { Survey in rural community, Peruvian Amazon, } \\
\text { Oxapampa province (Pasco) [NA] [1814 m] }\end{array}$ & 129 children and adults & $\begin{array}{l}\text { - Simple direct smear } \\
\text { - Spontaneous tube } \\
\text { sedimentation } \\
\text { - Baermann method modified } \\
\text { by Lumbreras } \\
\text { - Dancescu culture } \\
\text { - Agar plate culture technique }\end{array}$ & $38.5 \%$ \\
\hline $\begin{array}{l}\text { Yori PP } 2006 \\
{[11]}\end{array}$ & $\begin{array}{l}\text { Survey in rural community on Nanay River, } \\
\text { Amazon Basin (Loreto) }[100 \mathrm{~m}]\end{array}$ & 908 children and adults & $\begin{array}{l}\text { - Direct smear } \\
\text { - Baermann method } \\
\text { - Simple sedimentation } \\
\text { - ELISA positive }\end{array}$ & $\begin{array}{l}8.7 \% \\
72 \% \\
\text { seroprevalence }\end{array}$ \\
\hline $\begin{array}{l}\text { Garcia } 2006 \\
{[15]}\end{array}$ & $\begin{array}{l}\text { Cayetano Heredia National Hospital, Lima } \\
\text { (Lima) }[160 \mathrm{~m}]\end{array}$ & 217 patients with HIV/AIDS & $\begin{array}{l}\text { - Direct examination } \\
\text { - Kato-Katz technique } \\
\text { - Spontaneous tube } \\
\text { sedimentation } \\
\text { - Baermann method modified } \\
\text { by Lumbreras } \\
\text { - Rapid sedimentation technique } \\
\text { modified by Lumbreras } \\
\text { - Ziehl Neelsen stain }\end{array}$ & $6 \%$ \\
\hline $\begin{array}{l}\text { Crotti } 2007 \\
{[26]}\end{array}$ & Chacas Hospital (Lima) [3300-3500 m] & $\begin{array}{l}91 \text { patients ( } 38 \text { children }+53 \\
\text { adults) }\end{array}$ & $\begin{array}{l}\text { - Microscopic observations } \\
\text { (direct and after formalin-ether } \\
\text { concentration) } \\
\text { - Giemsa permanent stain }\end{array}$ & $0.3 \%$ \\
\hline
\end{tabular}


Table 1 Peruvian studies of Strongyloides stercoralis infection (Continued)

\begin{tabular}{|c|c|c|c|c|}
\hline Study ID & Setting (department) [altitude] & Population & Diagnostic procedure & $\begin{array}{l}\text { Prevalence } \\
\text { estimate }\end{array}$ \\
\hline $\begin{array}{l}\text { Natividad- } \\
\text { Carpio } 2007 \\
\text { [8] }\end{array}$ & $\begin{array}{l}\text { Community survey, Chancay district, Huaral } \\
\text { province (Lima) [161 m] }\end{array}$ & 173 children ( $2-20$ years-old) & $\begin{array}{l}\text { - Direct examination } \\
\text { - Spontaneous tube } \\
\text { sedimentation } \\
\text { - Rapid sedimentation technique } \\
\text { modified by Lumbreras } \\
\text { - Kato-Katz technique } \\
\text { - Baermann method, modified } \\
\text { by Lumbreras }\end{array}$ & $1.1 \%$ \\
\hline $\begin{array}{l}\text { Machicado } \\
2012[21]\end{array}$ & $\begin{array}{l}\text { Rural survey, Tambopata province (Madre de } \\
\text { Dios). Peruvian Rainforest [ } 200 \mathrm{~m}]\end{array}$ & 73 children ( $2-20$ years old) & $\begin{array}{l}\text { - Spontaneous tube } \\
\text { sedimentation } \\
\text { - Kato-Katz technique } \\
\text { - Modified Baermann method } \\
\text { - Agar plate culture } \\
\text { - Harada-Mori culture } \\
\text { - Direct smear examination }\end{array}$ & $16 \%$ \\
\hline $\begin{array}{l}\text { Cabada } 2014 \\
{[27]}\end{array}$ & $\begin{array}{l}\text { Rural survey following deworming campaign, } \\
\text { southern Peruvian Amazon (Madre de Dios) } \\
{[600 \mathrm{~m}]}\end{array}$ & $\begin{array}{l}290 \text { members of the } \\
\text { Matsiguenga ethnic group }\end{array}$ & $\begin{array}{l}\text { - Direct examination } \\
\text { - Rapid sedimentation } \\
\text { - Kato-Katz technique }\end{array}$ & $5.6 \%$ \\
\hline $\begin{array}{l}\text { Cabada } 2014 \\
{[22]}\end{array}$ & $\begin{array}{l}\text { Rural communities survey around Cusco } \\
{[3300-3500 \mathrm{~m}]}\end{array}$ & 227 children ( $3-12$ years old) & $\begin{array}{l}\text { - Direct examination } \\
\text { - Rapid sedimentation } \\
\text { - Kato-Katz technique }\end{array}$ & $0.9 \%$ \\
\hline $\begin{array}{l}\text { Cabada } 2016 \\
\text { [23] }\end{array}$ & $\begin{array}{l}\text { Rural survey communities around Cusco } \\
\text { (Cusco) }[3300-3500 \mathrm{~m}]\end{array}$ & 1230 children ( $3-16$ years old) & $\begin{array}{l}\text { - Lumbreras rapid sedimentation } \\
\text { tests } \\
\text { - Kato-Katz technique ( } 3 \\
\text { samples) }\end{array}$ & $2 \%$ \\
\hline $\begin{array}{l}\text { Garaycochea } \\
2018[28]\end{array}$ & $\begin{array}{l}\text { Provinces of Huaral, Oyón, Yauyos and } \\
\text { Huarochirí. (Lima) [188-3600-2800-3100 m] }\end{array}$ & 359 (children < 5 years old) & $\begin{array}{l}\text { - Direct sedimentation methods } \\
\text { - Heidenhain's iron hematoxylin } \\
\text { smear test } \\
\text { - Modified Ziehl Neelsen } \\
\text { - Graham's method }\end{array}$ & $6.8 \%$ \\
\hline $\begin{array}{l}\text { Morales } 2019 \\
{[29]}\end{array}$ & $\begin{array}{l}\text { Community survey, rural population around } \\
\text { Cusco: Quellouno [800 m] and Limatambo } \\
\text { [2554 m] [3300 m] }\end{array}$ & $\begin{array}{l}462 \text { participants (children and } \\
\text { adults) }\end{array}$ & $\begin{array}{l}\text { - Baermann's method } \\
\text { - Agar plate culture } \\
\text { - Sedimentation tests (1 sample) }\end{array}$ & $\begin{array}{l}24.5 \%^{*} \\
26.4 \%^{* *} \text { low } \\
\text { altitude } \\
18.6 \text { high } \\
\text { altitude }\end{array}$ \\
\hline Errea 2019 [9] & $\begin{array}{l}\text { Rural community surveys in Padre Cocha } \\
\text { (Amazon Basin) (Loreto) [100 m] }\end{array}$ & 124 children & $\begin{array}{l}\text { - Direct smear analysis } \\
\text { - Kato-Katz technique } \\
\text { - Spontaneous tube } \\
\text { sedimentation } \\
\text { - Baermann's method } \\
\text { - Agar plate culture (1 sample) }\end{array}$ & $10.5 \%$ \\
\hline $\begin{array}{l}\text { Ortiz-Martínez } \\
2020[17]\end{array}$ & $\begin{array}{l}\text { Survey, urban and periurban lquitos, Peruvian } \\
\text { Amazon (Loreto) }[100 \mathrm{~m}]\end{array}$ & 300 pregnant women (adults) & $\begin{array}{l}\text { - Baermann's method } \\
\text { - Charcoal culture } \\
\text { - Kato-Katz technique } \\
\text { - ELISA (1 sample) }\end{array}$ & $\begin{array}{l}10 \% \\
30 \% \\
\text { seroprevalence }\end{array}$ \\
\hline
\end{tabular}

Table 2 Pooled prevalence analysis of Strongyloides infection in different population groups

\begin{tabular}{lllllll}
\hline & Pooled prevalence & 95\% confidence intervals & N studies & N participants & I $^{\mathbf{2}}$ \% & Egger's test \\
\hline General pop. & 7.34 & $4.97-10.13$ & 16 & 51,094 & 97.51 & 0.315 \\
Children & 5.59 & $3.67-7.88$ & 13 & 15,793 & 94.70 & 1.301 \\
Adults & 6.99 & $4.24-103.5$ & 6 & 11,693 & 95.00 & -0.379 \\
\hline
\end{tabular}


heterogeneity in general and adult populations, although not in studies in children. Figures 2, 3 and 4 summarize the prevalence in general, pediatric, and adult populations.

\section{Discussion}

The prevalence of S. stercoralis varies by geographical area. Prevalence in the rainforest is $18.5 \%$; in the mountains, $2.2 \%$ (2300-3500 m altitude) to $4.3 \%$ (3500-4000 $\mathrm{m}$ altitude); and on the coast, 3.0\% [10]. In another study Strongyloides infection was more common at low altitudes (26.4\%) compared to high altitudes (18.6\%) [29]. Among the studies that collected several samples, the highest prevalence observed was $19.5 \%$ [24]. In contrast, two studies reported very low prevalence: 1.5 and $2 \%$ $[19,23]$, despite having increased the diagnostic yield with multiple samples. These differences are probably due to geographical factors, as the first study took place in the Peruvian Amazon and the other two at more than $3300 \mathrm{~m}$ altitude. The filariform larvae of $S$. stercoralis are known to survive for about 2 weeks at temperatures between $8{ }^{\circ} \mathrm{C}$ and $40^{\circ} \mathrm{C}$, but they cannot withstand excessive aridity or humidity [31]. This may be one reason why Strongyloides is more prevalent in the rainforest than in the mountains. On the other hand, mountain inhabitants may travel to the rainforest on a seasonal basis, which could explain why the prevalence is higher at $3500 \mathrm{~m}$ compared to $2300 \mathrm{~m}$.

Estimating the prevalence of $S$. stercoralis in Peru is complicated by the diversity of diagnostic methods used. Not all methods have the same ability to detect it. It would be necessary to systematize the studies using several diagnostic procedures (Baermann method, charcoal culture, and probably serology) to have a more accurate estimate of the true prevalence.

A study designed for diagnosing S. stercoralis infection in a rural community in Iquitos [11] showed that $8.7 \%$ of the stool samples were positive using one of three diagnostic methods, although the sensitivity differed between them: direct examination (sensitivity $37.7 \%$ ), Baermann method (40.5\%), or simple sedimentation (79.7\%). APC showed a sensitivity of just $60.9 \%$ due to an exuberant growth of fungi in $35 \%$ of the samples, which prevented interpretation. Enzyme-linked immunosorbent

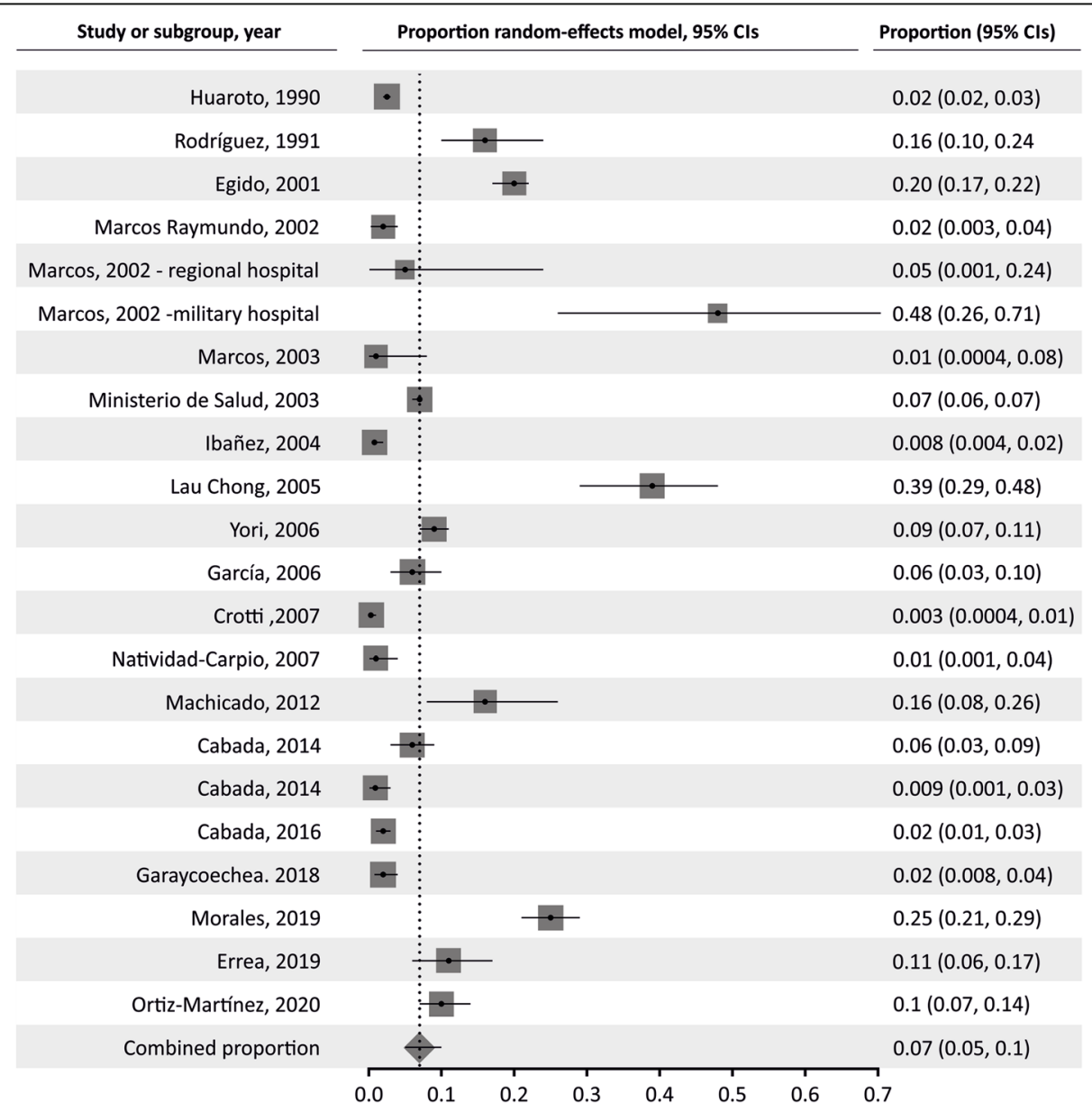

Fig. 2 Forest plot of pooled prevalence of Strongyloides infection in general population 


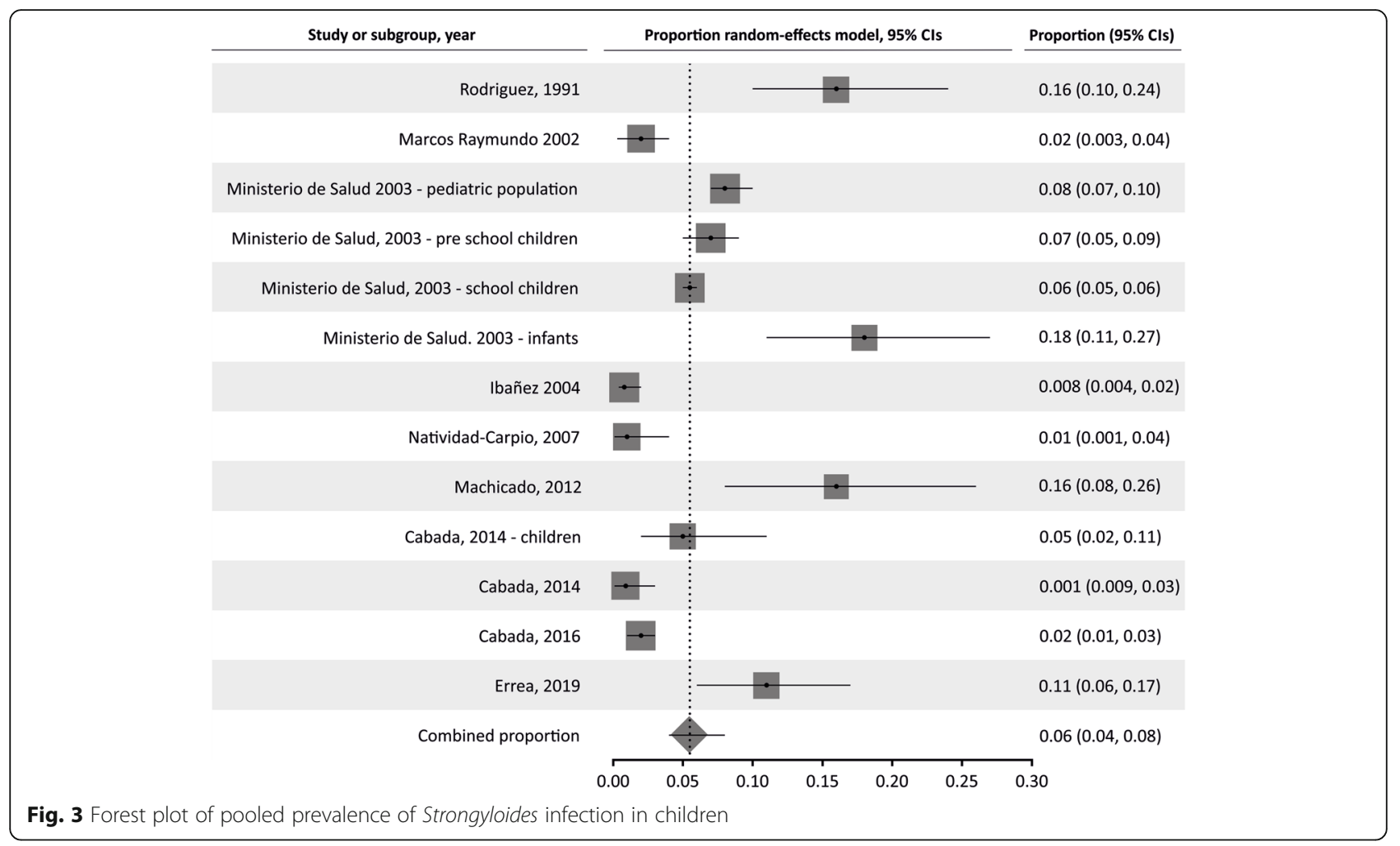

assay (ELISA) was positive in $72 \%$ of the blood samples, and the negative predictive value of the serology was $98 \%$. In another study from the same region, the prevalence of S. stercoralis infection was $10 \%$ using the Baermann method, charcoal culture and ELISA for diagnosis. In this case, the sensitivity of the serology was $63.3 \%$ and the negative predictive value, $94.4 \%$ [17].
Machicado et al. [21] calculated the percentage of samples positive for $S$. stercoralis with each diagnostic method, observing that APC was the most sensitive method (81\%), followed by the modified Baermann technique and SSTT (75\%). The sensitivity of the HaradaMori culture was much lower at $19 \%$, while the direct smear or Kato-Katz had $0 \%$ sensitivity. In the same

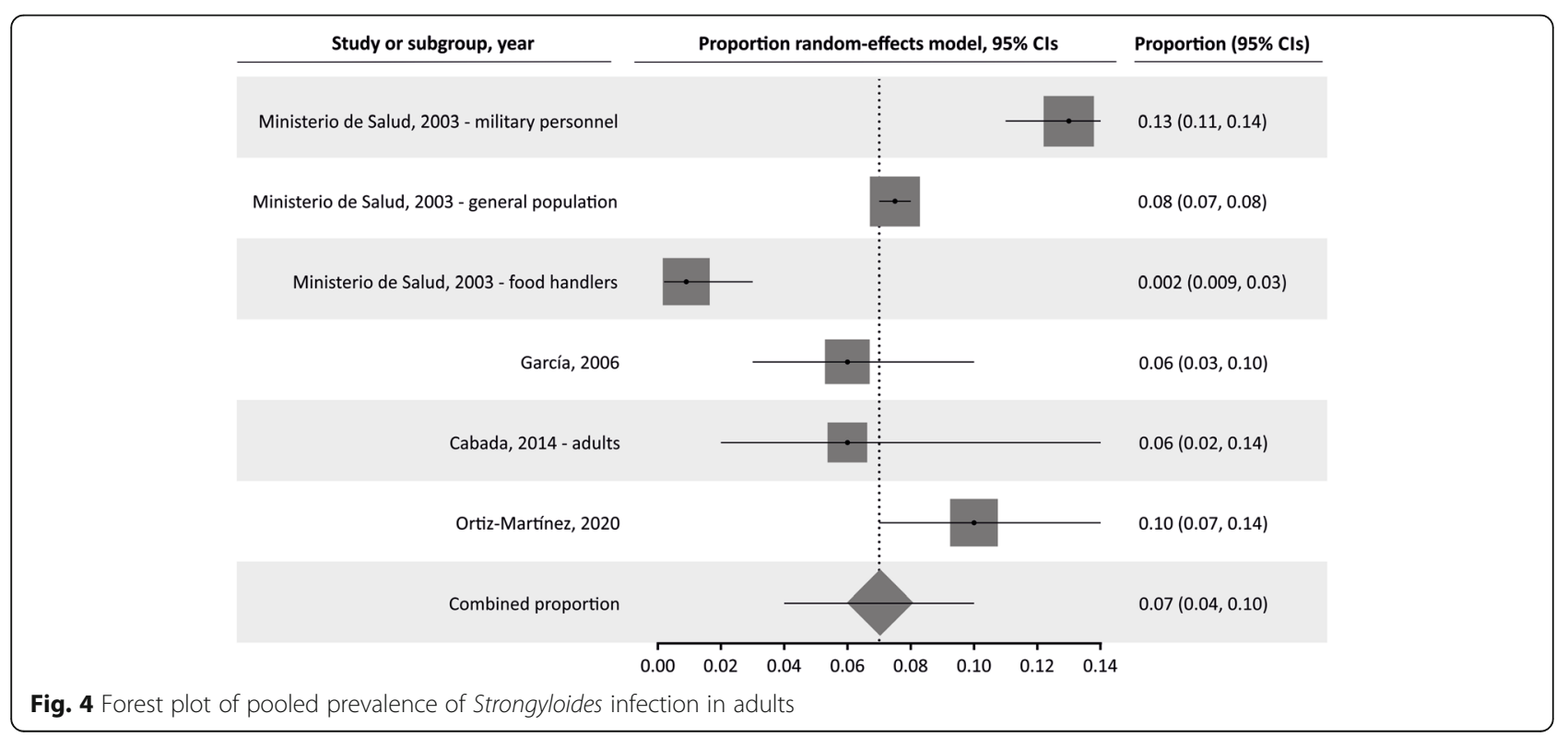


study, the authors found no difference in the number of diagnosed cases of A. lumbricoides, T. trichura, and hookworm, using either the Kato-Katz or spontaneous sedimentation in tube technique. Thus, the SSTT could be a good diagnostic method for S. stercoralis as well as other helminths.

Techniques such as Baermann's or APC are cumbersome and time-consuming. Multiple samples must be collected on different days to improve the detection rate because of the irregular excretion pattern of $S$. stercoralis larvae, especially for low-intensity infections. Another drawback is the need for fresh and non-refrigerated stool samples.

Serology is useful, but this method could overestimate the prevalence of the disease due to cross-reactivity with other nematode infections; moreover, distinguishing recent infections from past (and cured) ones is not straightforward [12].

The prevalence of strongyloidiasis varies according to the characteristics of the study population. The high prevalence in Marcos et al.'s study (45\%) can be attributed to the military population, which was exposed to untreated drinking water, lack of sanitation, overcrowding, and environmental risks during the course of their work [16]. These same conditions are found in rural communities where the studies with the highest prevalence take place $[7,21,29]$. The exception is the study by Egido et al. [24], where the population presents diarrhea; in the patients with symptoms (diarrhea) the prevalence of $S$. stercoralis as well as other pathogens was higher.

There is only one study carried out in pregnant women, showing a prevalence of $10 \%$. Similar prevalence $(10.5 \%)$ was observed in children in the same geographical area [9] and in the study by Yori et al. [11] in the general population $(8.7 \%)$. This suggests that prevalence in pregnant women may be similar to the rest of the population in the same area, but more studies would be necessary to confirm. Given that pregnant women are especially vulnerable to disseminated strongyloidiasis and hyperinfection due to the immunosuppression of pregnancy itself, chronic nutritional deficiencies, and the occasional use of corticosteroids for fetal lung maturation, it would be important to implement active search and control programs for S. stercoralis during antenatal visits.

Our review is limited by the relatively small number of included studies, the lack of standard definitions, the use of different diagnostic techniques, and the study of multiparasitosis.

\section{Conclusions}

Prevalence of S. stercoralis in Peru ranged from 0.3 to $45 \%$, with variations by geographic study area, stool examination techniques, and participant characteristics. Small-scale prevalence estimates within a country do not accurately reflect the variation in distribution. They are not necessarily representative of a country as a whole. Therefore, it would be necessary to establish a specific diagnostic protocol for S. stercoralis together with adequate sampling and statistical analysis to estimate the real prevalence of strongyloidiasis in Peru. This would be the starting point for the development of an integrated soil-transmitted helminthiasis control program.

\section{Abbreviations}

APC: agar plate culture; ELISA: Enzyme-Linked ImmunoSorbent Assay; SSTT: Spontaneous sedimentation in tube technique

\section{Acknowledgments}

We want to thank all members of the Spanish-Peruvian Chagas, HTLV and Strongyloides Network [J.M. Ramos-Rincón \& A. Gimeno (Hospital General Universitario Alicante \& Universidad Miguel Hernández, Alicante, Spain), J. Llenas-García (Hospital Vega Baja, Orihuela, Spain), E. de-Miguel-Balsa (Hospital General Universitario Elche \& Universidad Miguel Hernández, Alicante, Spain), M. Górgolas-Hernández-Mora, R. Pérez-Tanoira \& L. Prieto-Pérez (Hospital Universitario Fundación Jiménez-Díaz \& Universidad Autónoma de Madrid, Madrid, Spain), S. Ortiz-Martínez (Consultorio El Ballestero, Albacete, Spain), M.E. Vásquez-Chasnamote (Centro de Investigación de Recursos Naturales, Universidad Nacional de la Amazonia Peruana. Iquitos, Peru), O.N. Gamboa-Paredes, J. Parraguez-de-la-Cruz, J.J. Alarcón-Baldeón, P. SchillykGuerra, J. Bardales-Vásquez, G. Pérez-Bardales, A. Hernández-Vargas, T.

Zumaeta Silva, \& R.P. Pezo-Flores (Asociación Civil Selva Amazónica, lquitos, Perú), L.A. Espinoza-Venegas \& C. Ramal-Asayag (Hospital Regional de Loreto, Iquitos, Perú), V.V. Pinedo Cancino (Laboratorio de Biología Molecular e Inmunología de la Unidad Especializada, Universidad Nacional de la Amazonia Peruana \& Asociación Civil Selva Amazónica, lquitos, Perú) \& M. Casapía Morales (Hospital Regional de Loreto, Asociación Civil Selva Amazónica \& Universidad Nacional de la Amazonia Peruana, lquitos, Perú)] for their active contribution to the study. We also express our thanks to Meggan Harris for her assistance in editing this paper.

\section{Authors' contributions}

Conceptualization, J.-M.R.-R., M.G.H.M. and M.C.-M; Methodology, S.O.-M, M.E.V.-C, O.-N.G.-P, K.-M.A.-F, E.M-B and L.-A.E.-V; Formal Analysis, S.O.-M. and J.M.R.-R; Data Curation, S.O.-M. M.-E.V.-C, O.-N.G.-P, K.-M.A.-F, E.M-B, V.-V.P.-C and L.-A.E.-V.; Writing - Original Draft Preparation, S.O.-M, J.-M.R.-R., M.-G.H.-M. and M.C.-M; Writing - Review \& Editing, S.O.-M, J.-M.R-.R., M.-E.V.-C, O.-N.G.-P, K.M.A.-F, L.-A.E.-V, E.M-B, M.-G.H.-M. and M.C.-M. All authors have read and approved the manuscript.

\section{Funding}

This research was co-funded by the University Development Cooperation Program, Miguel Hernández University of Elche and Generalitat Valenciana. Grant number [SOLCIF/2017/0005] in the design of the study and collection, analysis, and interpretation of data.

\section{Availability of data and materials}

The datasets generated are available from the corresponding author on reasonable request.

\section{Declarations}

Ethics approval and consent to participate Not applicable.

Consent for publication Not applicable.

Competing interests

The authors have declared no conflict of interest. 


\section{Author details}

'Medical Practice El Ballestero, Health Service of Castilla La Mancha, Albacete, Spain. ${ }^{2}$ Clinical Medicine Department, University Miguel Hernández of Elche, Ctra N-332, 03550 Sant Joan d'Alacant, Alicante, Spain. ${ }^{3}$ Internal Medicine Service, General University Hospital of Alicante-ISABIAL, Alicante, Spain. ${ }^{4}$ Natural Resources Research Center. National University of the Peruvian Amazon, Iquitos, Peru. ${ }^{5}$ Research Assistant. Amazon Rainforest Civil Association, lquitos, Peru. ${ }^{6}$ Infectious Diseases and Tropical Medicine Service, Loreto Regional Hospital, Iquitos, Peru. ${ }^{7}$ Intensive Care Unit, General University Hospital of Elche, Alicante, Spain. ${ }^{8}$ Molecular Biology and Immunology Laboratory of the Specialized Unit of LIPNAA-CIRNA, National University of the Peruvian Amazon, Iquitos, Peru. Infectious Disease Division, University Hospital Foundation Jiménez Díaz, Madrid, Spain. ${ }^{10}$ Medicine Department, Autonomous University of Madrid, Madrid, Spain. ${ }^{11}$ Medical Department, Amazon Rainforest Civil Association, Iquitos, Peru. ${ }^{12}$ School of Medicine, National University of the Peruvian Amazon, lquitos, Peru.

Received: 4 January 2021 Accepted: 16 July 2021

Published online: 04 August 2021

\section{References}

1. Krolewiecki A, Nutman TB. Strongyloidiasis: a neglected tropical disease. Infect Dis Clin N Am. 2019;33(1):135-51. https:/doi.org/10.1016/j.idc.2018.10.006.

2. Schär F, Trostdorf U, Giardina F, Khieu V, Muth S, Marti H, et al. Strongyloides stercoralis: global distribution and risk factors. PLoS Negl Trop Dis. 2013;7(7): $1-17$.

3. Bisoffi Z, Buonfrate D, Montresor A, Requena-Méndez A, Muñoz J, Krolewiecki AJ, et al. Strongyloides stercoralis: a Plea for action. PLoS Negl Trop Dis. 2013;7(5):7-10.

4. Buonfrate D, Bisanzio D, Giorli G, Odermatt P, Fürst T, Greenaway C, et al. The global prevalence of Strongyloides stercoralis infection. Pathogens. 2020; 9(6):468. https://doi.org/10.3390/pathogens9060468.

5. Van De N, Minh PN, Van Duyet L, Mas-Coma S. Strongyloidiasis in northern Vietnam: epidemiology, clinical characteristics and molecular diagnosis of the causal agent. Parasites Vectors. 2019;12(1):1-12

6. Guevara AG, Anselmi M, Bisoffi Z, Prandi R, Márquez M, Silva R, et al. Mapping the prevalence of Strongyloides stercoralis infection in Ecuador: a serosurvey. Am J Trop Med Hyg. 2020 Dec;102(2):346-9. https://doi.org/1 0.4269/ajtmh.19-0565.

7. Lau Chong C, Samalvides Cuba F, Terashima IA. Evaluación de técnicas parasitológicas en el diagnóstico de estrongiloidiasis por Strongyloides stercoralis. Rev Med Hered. 2005;16(1):11-8.

8. Natividad Carpio I, Reyes Díaz J, Trelles de Belaunde M, Viguria Chávez Y, Yabar Bedoya D, Terashima Iwashita A. Presencia de Strongyloides stercoralis en un estudio sobre enteroparasitosis en escolares del asentamiento humano "La Candelaria", distrito de Chancay, provincia de Huaral, departamento de Lima. Acta Med Peru. 2007;24(3):177-80.

9. Errea RA, Vasquez-Rios G, Calderon ML, Siu D, Duque KR, Juarez LH, et al. Soil-transmitted helminthiasis in children from a rural community taking part in a periodic deworming program in the Peruvian Amazon. Am J Trop Med Hyg. 2019 Sep;101(3):636-40. https://doi.org/10.4269/ajtmh.18-1011.

10. Ministerio de Salud del Perú. Helmintos Intestinales en el Perú: Análisis de la Prevalencia (1981-2001). Oficina General de Epidemiología [Internet]. Lima, Perú; 2003. Available from: http://www.dge.gob.pe/publicaciones/pub_ invepi/iepi06.pdf

11. Yori PP, Kosek M, Gilman RH, Cordova J, Bern C, Chavez CB, et al. Seroepidemiology of strongyloidiasis in the Peruvian Amazon. Am J Trop Med Hyg. 2006;74(1):97-102. https://doi.org/10.4269/ajtmh.2006.74.97.

12. Requena-Méndez A, Chiodini P, Bisoffi Z, Buonfrate D, Gotuzzo E, Muñoz J. The Laboratory Diagnosis and Follow Up of Strongyloidiasis: A Systematic Review. PLoS Negl Trop Dis. 2013;7(1):e2002.

13. LA Marcos R, Canales M, Terashima A. Métodos de diagnóstico para Strongyloides stercoralis en el Perú. Rev Peru Parasitol. 2010;18(1):e6-9.

14. Wang K-S, Liu X. Statistical methods in the meta-analysis of prevalence of human diseases. J Biostat Epidemiol. 2016;2(1):20-4.

15. García C, Rodríguez E, Do N. López de Castilla D, Terashima a, Gotuzzo E. intestinal parasitosis in patients with HIV-AIDS. Rev Gastroenterol Peru. 2006; 26(1):21-4.

16. Marcos L, Maco V, Machicado A, Samalvides F, Terashima A, Quijano C, et al. Diferencias de Prevalencia de Parasitosis Intestinal entre los Hospitales Militar y Regional de Iquitos. Loreto-Peru Diagnostico. 2002;41(4):185-7.
17. Ortiz-Martínez S, Ramos-Rincón JM, Vásquez-Chasnamote ME, AlarcónBaldeón JJ, Parraguez-De-La-Cruz J, Gamboa-Paredes ON, et al. A crosssectional study of seroprevalence of strongyloidiasis in pregnant women (Peruvian amazon basin). Pathogens. 2020;9(5):348. https://doi.org/10.3390/ pathogens 9050348.

18. Rodríguez J, Calderón J. Intestinal parasitosis in pre-school children from Tarapoto. Rev Gastroenterol Peru. 1991;11(3):153-60.

19. Marcos Raymundo Luis A, Vicente MF, Angélica TI, Samalvides Cuba Frine GHE. Prevalencia de parasitosis intestinal en niños del valle del Mantaro, Jauja, Perú. Rev Med Hered. 2002;13(3):85-90.

20. Ibáñez Herrera N, Jara CC, Guerra MA, Díaz Limay E. Prevalencia de enteroparasitismo en escolares de comunidades nativas del Alto Marañón, Amazonas, Perú. Rev Peru Med Exp Salud Publica. 2004;21(3):126-33.

21. Machicado JD, Marcos LA, Tello R, Canales M, Terashima A, Gotuzzo E. Diagnosis of soil-transmitted helminthiasis in an Amazonic community of Peru using multiple diagnostic techniques. Trans R Soc Trop Med Hyg. 2012 106(6):333-9. https://doi.org/10.1016/j.trstmh.2012.03.004

22. Cabada MM, Goodrich MR, Graham B, Villanueva-Meyer PG, Lopez M, Arque E, et al. Fascioliasis and eosinophilia in the highlands of Cuzco, Peru and their association with water and socioeconomic factors. Am J Trop Med Hyg. 2014;91(5):989-93. https://doi.org/10.4269/ajtmh.14-0169.

23. Cabada MM, Morales ML, Lopez M, Reynolds ST, Vilchez EC, Lescano AG, et al. Hymenolepis nana impact among children in the highlands of Cusco, Peru: an emerging neglected parasite infection. Am J Trop Med Hyg. 2016; 95(5):1031-6. https://doi.org/10.4269/ajtmh.16-0237.

24. Egido JM, De Diego JA, Penin P. The prevalence of enteropathy due to strongyloidiasis in Puerto Maldonado (Peruvian Amazon). Braz J Infect Dis. 2001;5(3):119-23. https://doi.org/10.1590/s1413-86702001000300003.

25. Marcos L, Maco V, Terashima A, Samalvides F, Miranda E, Gotuzzo E. Parasitosis intestinal en poblaciones urbana y rural en Sandia, Departamento de Puno, Perú. Parasitol Latinoam. 2003;58(1-2):35-40.

26. Crotti D, D'Annibale ML, Basileo M, La Torre G. Preliminary survey of human intestinal parasitosis in a Peruvian Andean zone. Infez Med. 2007;15(3):181-6.

27. Cabada MM, Lopez M, Arque E, White AC. Prevalence of soil-transmitted helminths after mass albendazole administration in an indigenous community of the Manu jungle in Peru. Pathog Glob Health. 2014;108(4): 200-5. https://doi.org/10.1179/2047773214Y.0000000142.

28. Garaycochea M, Beltrán M. Parasitosis intestinales en zonas rurales de cuatro provincias del departamento de Lima. Bol Inst Nac Salud. 2018;24(7-8):89-95.

29. Morales ML, Lopez M, Ly P, Anjum S, Fernandez-Baca MV, Valdivia-Rodriguez AM, et al. Strongyloides stercoralis infection at different altitudes of the Cusco region in Peru. Am J Trop Med Hyg. 2019 Aug;101(2):422-7. https:// doi.org/10.4269/ajtmh.18-0568.

30. Huaroto Sedda M, Osorio Naupari M, Ayala EL. Study of Strongyloides stercoralis in the duodenal juice obtained by the examination of a string capsule or the Enterotest. Rev Gastroenterol Peru. 1990;10(3):107-10.

31. Arango $\mathrm{JH}$, Strongyloides D. Strongyloides stercoralis. Colomb Med [Internet]. 1998;29:32-42 Available from: https://colombiamedica.univalle. edu.co/index.php/comedica/article/view/86.

\section{Publisher's Note}

Springer Nature remains neutral with regard to jurisdictional claims in published maps and institutional affiliations.

Ready to submit your research? Choose BMC and benefit from:

- fast, convenient online submission

- thorough peer review by experienced researchers in your field

- rapid publication on acceptance

- support for research data, including large and complex data types

- gold Open Access which fosters wider collaboration and increased citations

- maximum visibility for your research: over $100 \mathrm{M}$ website views per year

At BMC, research is always in progress.

Learn more biomedcentral.com/submission 